\title{
The Systematic Use of Corporate Social Responsibility by Small Companies
}

\author{
Stanislava Simonova ${ }^{1, *}$ and Kristyna Vrabcova $^{2}$ \\ ${ }^{1}$ University of Pardubice, Faculty of Economics and Administration, Pardubice, Czech Republic \\ ${ }^{2}$ University of Pardubice, Faculty of Economics and Administration, Pardubice, Czech Republic
}

\begin{abstract}
.
Research background: The responsibility of organizations towards their surroundings and society is a long-term strategic goal, which is supported by various projects and concepts, at the national, and global levels. The conception of sustainable development represents a model of society development, where economic and social development should be in line with the preservation of natural values for present and future generations.

Purpose of the article: The concept of Corporate social responsibility (CSR) is a voluntary commitment of an organization that wants to behave responsibly towards its surroundings. The concept is generally understood as a strategic initiative and it is applied mainly by large companies. Small and medium-sized companies are rather not interested in the concept, they are afraid of the burden for the company. The paper focuses on the potential of systematic use of the CSR concept by small organizations.

Methods: The survey was conducted in selected small organizations. The degree of acquaintance with the principles of the concept and especially with the possibilities of the concept was determined, the current state was analyzed and activities for implementation were proposed, and indicators for long-term monitoring were proposed.

Findings \& Value added: CSR concept encourages the company to make a positive impact on the environment. Small organizations often apply some of its principles, unknowingly by their natural responsible behavior. However, a systems-conscious approach is important. Small businesses can use the potential of the concept and implement its principles for the benefit of themselves and their surroundings.
\end{abstract}

Keywords: corporate social responsibility; small and medium-sized companies; sustainable development; society development

JEL Classification: $R 11 ; O 44 ; Q 01$

\footnotetext{
*Corresponding author: Stanislava.Simonova@upce.cz
} 


\section{Introduction}

The responsible behaviour of the companies is the important current requirement for creating the values and preserving these values for the future. The concept of the 'Corporate Social Responsibility - CSR' can be characterized as 'the responsibility of enterprises for their impacts on society' [1]. The concept represents the voluntary commitment of the company that the company will take into account the needs of the customers, suppliers, employees, and other representatives while decision making and in everyday activities whose work is touched directly or indirectly. The important part is also the effort of the organization to minimize the negative impacts of its activities on the environment [2-3]. The concept helps the companies to their responsible and sustainable business. The longlasting sustainable development is the societal theme, from the social, ecological, and economical point of view [4-5]. The state can support the spreading this concept so that it creates the conditions for the general understanding of the concept by the motivating and also coordinating the companies. The strategic document for the social responsibility development in the Czech Republic has its name 'The National Action Plan for Corporate Social Responsibility in the Czech Republic 2019-2023' [6]. The document defines the specific activities and strategic priorities such as - creating a suitable environment and tools for the support of the CSR implementation, getting involved actively in the international cooperation in the CSR area and sustainable development, etc. The document emphasizes the influence of the CSR concept on life quality improvement and also the direct context of the CSR concept and sustainable development.

\section{Methodological Framework}

The responsible behaviour of the companies is part of the whole sustainable development. The conception of sustainable development represents a model of the society development, which reflects the natural environmental limits of economic growth. Economic and social development should be aligned to ecosystem capacities, hand in hand with conservation of the natural values for present and future generations [7] (see Fig.1).

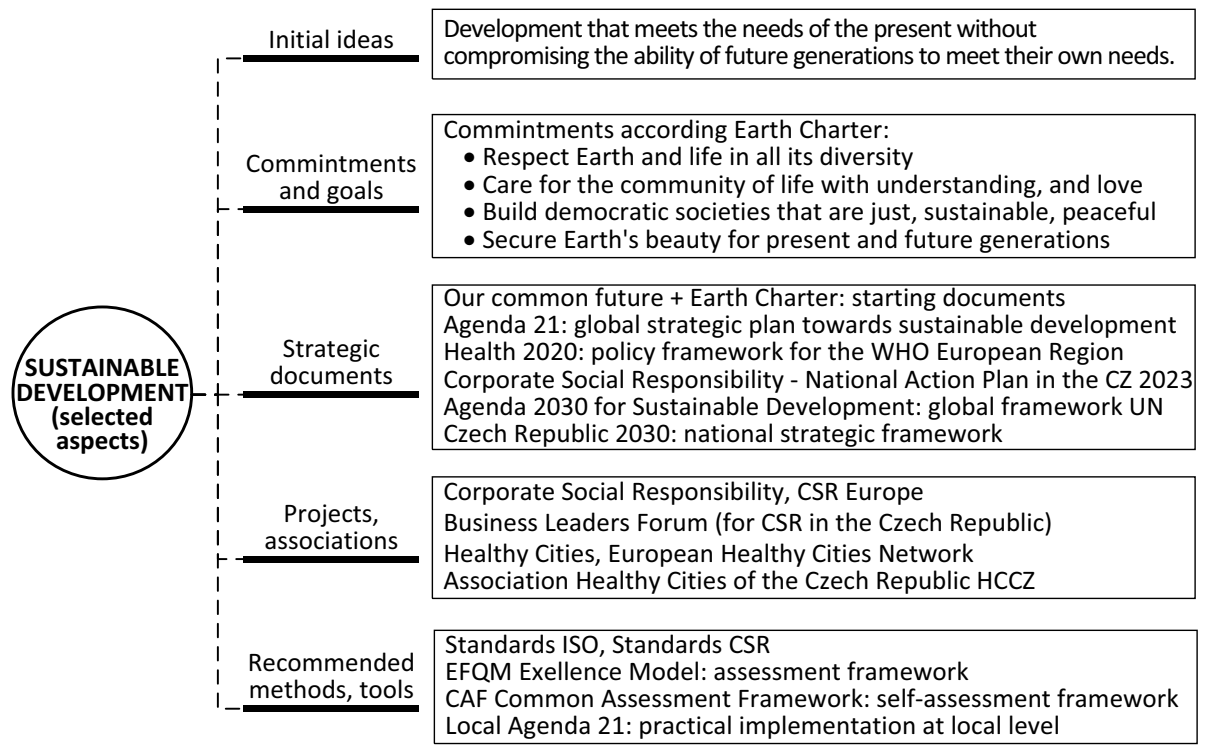

Fig. 1. Basic aspects of Sustainable Development. 
The need for the provision of sustainable development is changed for many years. The basic definition of this concept could be found in the document 'Our common future', committee WCED (UN World Commission on Environment and Development), where the definition is mentioned: 'Sustainable development is a development that meets the needs of the present without compromising the ability of the future generations to meet their own needs'. Default principles of the sustainable development were defined in the document 'The Earth Charter'.

\subsection{Projects for Sustainable Development}

International project 'Healthy Cities' represents the movement of the European municipalities and regions, which systematically goes towards the quality of life and health of their inhabitants. Participating cities associate to European Healthy Cities Network [8]. Project is developed in accordance with accepted strategic documents; there belong e.g. the global framework '2030 Agenda for Sustainable Development' and its '17 Sustainable Development Goals" (adopted in 2015 by all Member States of the UN) [9], the policy framework for the WHO European Region - 'The Health 2020' (adopted in 2012 during the session of the WHO Regional Committee for Europe) [10], the strategic framework 'Czech Republic 2030" (aim is to route our country to the development, which will be sustainable from a social, economic and environmental point of view) [11].

The conception 'Corporate Social Responsibility' (CSR) is the platform for those organizations looking to enhance sustainable growth and positively contribute to society.

Public authorities, including the EU, have an important role in supporting and encouraging companies to conduct their business responsibly. A smart mix of voluntary and mandatory actions was introduced to promote CSR, and implement the UN guiding principles on business and human rights and the UN 2030 agenda for sustainable development [12-13]. CSR Europe is the European business network for Corporate Sustainability and Responsibility [14-15]. This network involves many enterprises at the local, European and global levels; the aim is - to support businesses and industry sectors in their transformation and collaboration towards practical solutions and sustainable growth. The concept of the Corporate Social Responsibility means the voluntary commitment of the company, that will behave responsibly towards the influenced environment. The company has the responsibility towards its owners, as well as towards its environment. CSR comprises voluntary acceptance of the high ethical business standards, minimizes the negative impacts of its activities towards the environment, have good relationships with its employees, and supports the region, where the company has its business. The representative of the CSR in the Czech Republic is the Ministry of Industry and Trade. 'The National Information Portal about CSR' was created (https://www.narodniportal.cz/). Current aims and activities of the CSR in the Czech Republic are defined in the document 'The National Action Plan for Corporate Social Responsibility in the Czech Republic 2019-2023' [5].

Aiming the CSR concept is still developed and widened, as it is mentioned in the texts of many different authors. Nevertheless, the main pillars can be defined [16]:

- Economic pillar: activities in the economic area are directly related to the economic activity of the company, e.g. ethical behaviour, avoiding corruption, credibility, transparency, long-lasting building relationships with the customers and, suppliers;

- Social pillar: the aiming group of the social CSR activities can be the employees of the company, their families, or the people who live in their surroundings, and

- Environmental pillar: the three problematic fields include using the sources, the waste, and the air-water-soil pollution. 


\subsection{Approaches}

Strategic documents define the main visions and principles of sustainable development concepts. Implementations of the specific project have different approaches, which are related to different aspects:

- One aspect is the level of implementation, which can be global, national, or local.

- Another aspect is the type of company, i.e. if the company is the organization of the public administration or the private company.

- The important is also how big the company is because the awareness about the main conceptional principles and other implementing conditions is different among the workers in the big company and the workers in the small local firm.

E.g. Agenda 21 is a global comprehensive plan of action to be taken globally, nationally, and locally by organizations in every area in which human impacts on the environment. Human settlements are critical sites for the implementation of these universal global objectives, indicating the need for local action that serves global and local interests [17]. Local Agenda 21 is a practical tool for applying concrete principles of sustainable development in the local conditions. The agenda's vision has caused a number of innovations in municipal policies in environmental, social, and economic terms [18]. Governing sustainability should be about finding creative ways for opening spaces for participation and change, that is, for creating alternative ideas, practices, and social relations [19-20]. Citizen participation is important, state and local governments have to be interested not only in improving their performance but also in maintaining public confidence in the implementation of public services [21]. Also, the Czech Republic has a growing number of municipalities and regions that work with Local Agenda 21, its implementation is supported financially and methodically by national institutions [22].

CSR expresses the companies' orientation towards long-term goals and intervenes in all areas of the company. Among the most important benefits can belong [16] - the company becomes the sought-after employer, a bigger interest from the investor's point of view and disclosure of the other capital, reputation improvement in the eyes of the general public, good evaluation with business partners and possibilities of acquiring new partners, increase in sales and customers loyalty, reduction of operating costs and increase of operational efficiency, improvement of the awareness of the stakeholder's needs and possibility of development in the better quality cooperation.

Before implementing the CSR the company should always consider different options, which can or cannot be offered by CSR [23]. The important is always the cooperation with the stakeholders and their support. The company must have clear goals, in which direction to develop. Every implementation has its advantages and disadvantages (see Fig. 2).

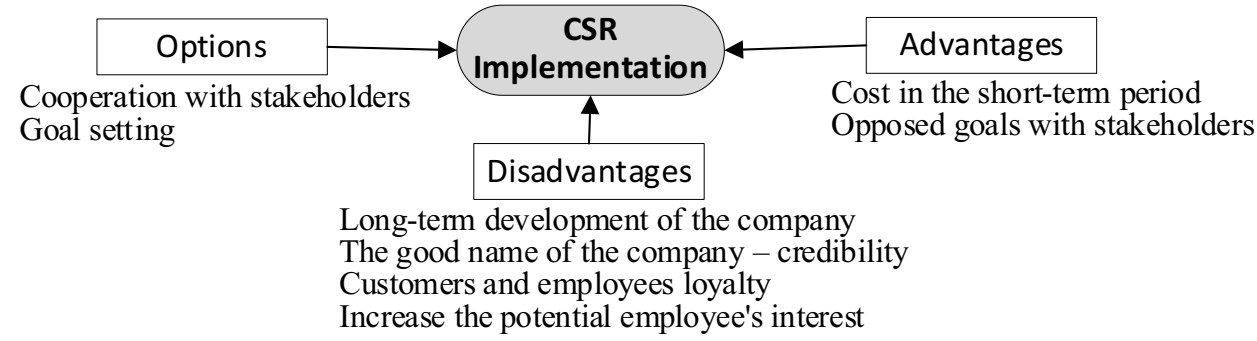

Fig. 2. Aspects of CSR implementation.

\section{Case study results - the Use of CSR by Small Companies}


As it was mentioned above, while the CSR principals implementation, it is important how big the company is, because the awareness of the main concept principles and different implementation conditions is different in the big companies and different in the local firms.

The CSR implementation within the big company is usually part of the company's policy. Management of the company considers this desirable and its own realization is real because the company can set aside financial and human sources for the CSR implementation. As the example of the CSR principles implementation in the big company can be shown the company TPCA Automobile (Toyota Peugeot Citroën Automobile) in Kolín (http://www.tpca.cz/). TPCA is a joint- venture of Toyota Motor Corporation and PSA Group. It belongs to the category of big companies because it employs 2500 employees. TPCA defines its mission as 'To be a good employer, neighbour, and citizen of the Czech Republic' [24]. The CSR concept implementation in TPCA is focused on social, economic, and environmental fields when the specific theme, activities, and projects are generated. Projects come out of both parent companies strategies (Toyota and PSA), when e.g. in case of environment protection is put long-term emphasis to $\mathrm{CO} 2$ production reduction, to the reduction of the energy consumption (water consumption, electricity, etc.) and to the stakeholders' engagement to the projects within the environmental problems. TPCA builds its own image as a 'Green factory'.

However, the situation is different in small companies. The CSR implementation within the small company is difficult, i.e. it is not implemented purposefully [25]. Small firms cannot set aside financial and human sources. The management of the small firm is not usually aware of the principles and possibilities of the CSR. It usually happens that the CSR activities are naturally implemented in the firm, without the firm's awareness. The requirement for small firms is to implement the CSR principles systematically. This is important from the view of the firm's existence itself as well as the global view of sustainable development. The case study was focused on small firms. Four regional firms were selected, they were contacted and the case study was explained to them. Information was gained and verified by repeated personal interviews with employees and managers. The main goal was to find out, how much the employees of both firms know about the CSR concept and if the firm applies it somehow, respectively some of their principles.

The following method was set:

1. Introduction of the main CSR principles to the firms' representatives and determining the main areas for the analysis. Goal = to determine the areas based on the CSR concept, which are considered important by the management.

2. Determine the evaluation criteria for every area. Goal = to realize and determine, which criteria characterize and influence the monitored area.

3. Evaluate the criteria via questionnaire, i.e. find out the current state once. Goal = to find out how much is the firm aware of the CSR and how much they fulfil or do not fulfil the selected CSR principles.

4. Suggest the recommendation for the improvement of the current state and determine the criteria for long-term repeated monitoring. Goal = to create the conditions for long-term criteria evaluation, if there is an improvement in the area of principles application of sustainable development.

\subsection{Determining the main areas}

On the basis of the introduction interviews, there were set three areas that are necessary to focus on. They are three areas for the other analysis. These areas come out of the CSR principles and the managers of the firms considered them important. These areas were called - Quality customer service; Satisfied customer; Environmental friendliness.

Every area was then briefly characterized as follows: 
- Quality service is given by the firm's approach when it is important to maintain active relationships with customers and solve the potential problems on time. The important is transparency and employees aware of the changes towards the customers' relationships.

- Satisfied employee works in a good environment from the view of teamwork, as well as the environment. The satisfied employee has the possibility of education and work on their development, they appreciate the firm's helpfulness e.g. in terms of benefits.

- Environmental friendliness is to find more economical ways while firms operation, it can reflect the choice of suppliers, then it is determined by the employee's behaviour.

\subsection{Determining the evaluation criteria for every area}

Every field was analyzed and there were determined causes - criteria, which have an influence on the required result. These fields were consulted several times with the selected managers and employees of the firms.

When determining the criteria it was necessary, that every field was specified by these criteria. This means, that it was understood, which aspects can have the influence onto the specific field. As a supporting tool in the interviews and determining, a tool that proved itself well was 'a Cause and Effect Diagram', especially for its visualization and mainly as an aid for the criteria identification itself (see Fig. 3).

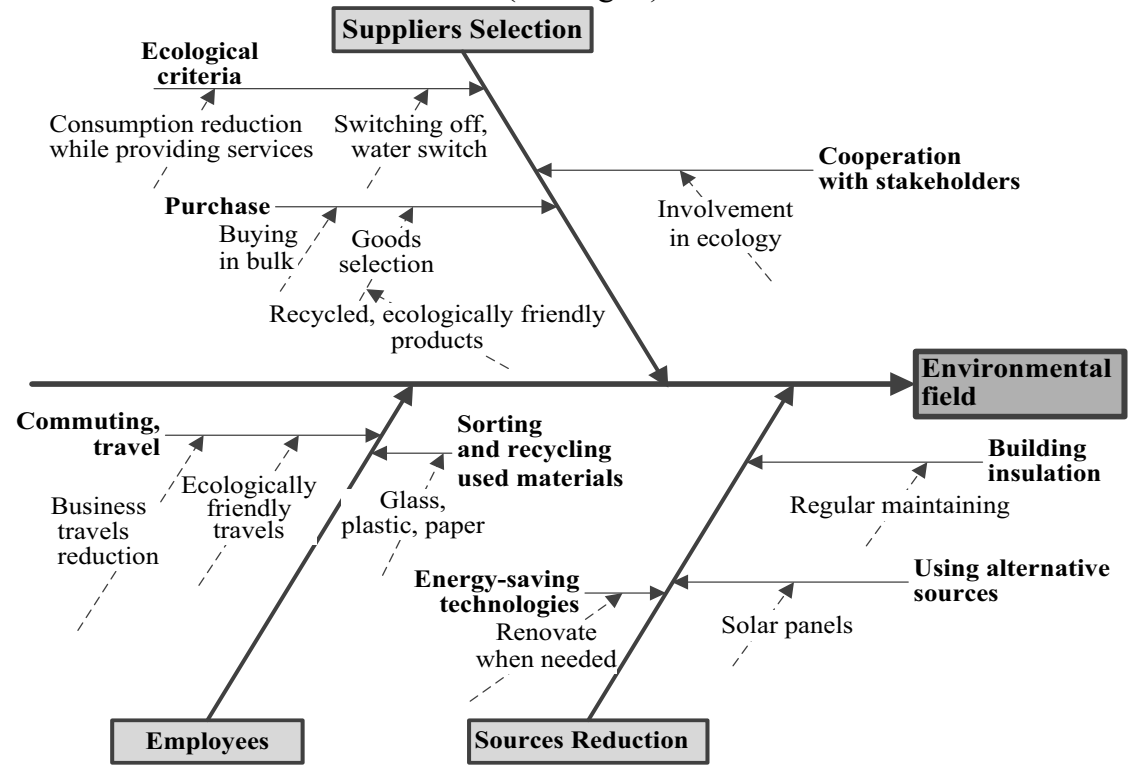

Fig. 3. Determining the evaluation criteria for environmental field

As an example let's show the Environmental field, what the firm could do for the more environmentally friendly behaviour. Within the Cause and Effect Diagram, there were determined three categories. The first category with the name 'Selection of the supplier' relates to many different criteria for the choice of the supplier. Ecological criteria were classified here, among them there also belong to the reduction of the consumption during the production (electricity, water, raw materials, waste) and waste disposal. For the supplier's selection was assigned also the cooperation with stakeholders and their involvement in ecology. Of course, it must not be missed the supplier selection when purchasing, where it is possible to choose either recycled goods or ecological products and ecologically friendly production. Another category was determined 'Saving resources', i.e. activities which help to save the resources. There is overall insulation of the building, 
which should be maintained regularly or using alternative sources (e.g. roof solar panels). Also using energy-saving technologies should be taken into account while innovating. The last identified criterium is 'Employees'. They can contribute to their own behaviour to the environmental field. After the interview it was included business travel reduction (more rigorous assessment of their necessity), also supporting the ecologically friendly commuting to work (there belong cycling or walking to work). Then sorting the waste and its recycling belongs here too, as well as from the employers' side and the employees' side. Employers should enable the possibility to sort waste easily.

The evaluation criteria were identified in the same way for all main monitored areas.

\subsection{Finding out the current state by questionnaire once}

The goal of the questionnaire was to find out the actual approach of the firm in the CSR field and if this concept is aware by the employees. For the question's formulation were not used all the identified criteria from the Cause and Effects diagrams, but on the basis of the dialogue, the criteria were narrowed. The reason was the requirement, that the questionnaire should be a basis for the initial finding of the current state and should not be overwhelming for respondents. Outputs from the questionnaire were presented in a graph and evaluated. As the example of the output can be shown the graphic visualization at the answers to the three questions related to the environment (see Fig. 4):

- Does your firm monitor its impact on the environment?

- Do you sort the waste at the workplace from your own will (plastics, glass, paper)?

- Do you have the possibility to sort or recycle the waste at your workplace?

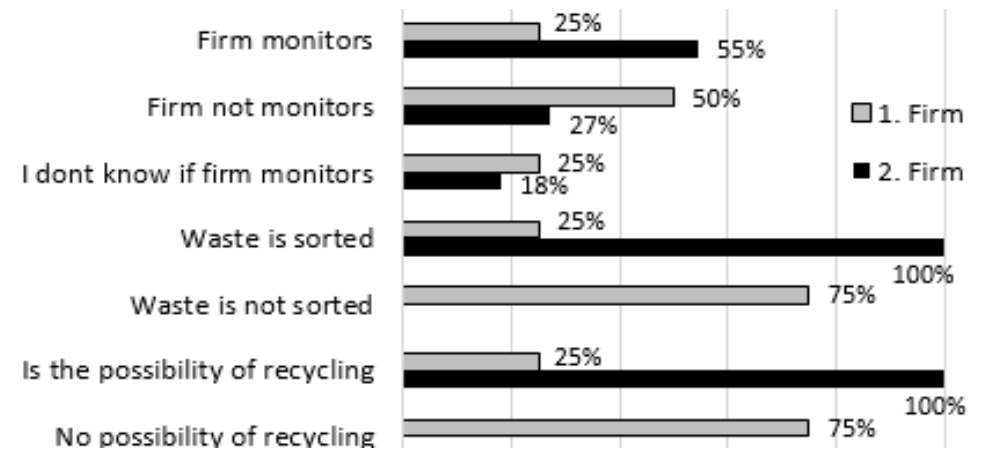

Fig. 4. The graphic visualization at the answers to the three questions related to the environment field.

Outputs gave the firms the feedback, that they actually use some of the CSR principles. It was stated in the discussion, that the CSR concepts are desirable for the firm itself, it is useful and feasible, and it is suitable to implement it more systematically.

Evaluation of the questionnaire provided the following results - e.g.:

- Engagement and awareness of the CSR respondents: In both firms the respondents participate in social responsible activities, mostly in recycling and sorting the waste, they also try to save the natural resources. Most of the respondents do not know what the social responsible firm is or they do not consider their activities as social responsible. They would also prefer to be employed at the social responsible firm.

- Economic field: There appeared the reserves in 'inner information' and reserves in communication. e.g. employees know about the Ethic Codex, but they do not know its content; or the employees have very low knowledge about defined rules of the behaviour towards the customers, etc. About the quality of the provided services, the 
respondents prefer the quality, and they believe that their behaviour is very good towards the customers, potential complaints and problems are solved.

- Environmental field: There also appeared some ignorance of the respondents about the firm policy in this field. Employees are not aware of the economical behaviour of the firm, they suggest using minimal chemicals and water and energy consumption reduction.

- Social field: In the field of education and development there were more answers that this support is missing or the employees do not know about it. Suggested benefits would be - contributions to the pension or life insurance, training sessions, meal vouchers.

\subsection{Recommendation for the improvement of the current state and determining the criteria for long-term monitoring}

The goal was to improve the current state and create the conditions for long-term criteria evaluation so that it would be possible to control if the principles of sustainable development are improving or not. Representatives of both firms used the results of the questionnaire as an inspiration for improvement. Among the suggested measures belong:

- create the conditions for consistent sorting the waste,

- create regular meetings with employees, where it is possible to inform the employees about the news and get feedback about the employees' ideas of improvement,

- discuss the possible benefits with employees so that it would suit the firm as well as employees,

- up-date the ethic codex so that it will become the 'life' helping material for providing the services to the customers.

Then the criteria for long-term monitoring and evaluation were selected. For the economic field, the criteria were determined, focused on Complaints, Claims, and Employees fluctuation. For the social field, the criteria were determined, focused on Education and Training and Benefits. For the Environmental field, the criteria were determined, focused on Energy saving, Firm operation, and Sorting and Recycling of the material. Suggested criteria for the long-term monitoring in the environmental field are on the Figure no. 5).

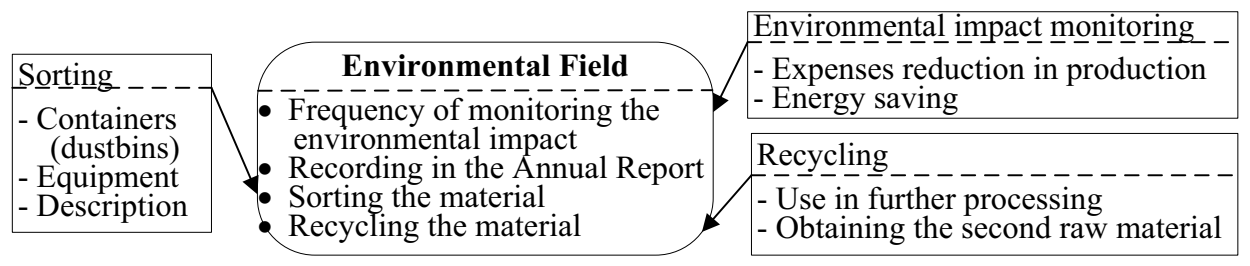

Fig. 5. The criteria for long-term monitoring and evaluation for the Environmental field.

\section{Discussions}

Implementation of the CSR concept contributes to the quality life improvement and has a direct context with the sustainable development concept. Implementation of the CSR in the companies is motivated by projects of the state, but it is a voluntary commitment of the company and it depends on the more factors. The important circumstance is how big the company is. The different awareness about the main principles of the concept and different implementation conditions have workers in the big company and the different situation is in the small local firms. Implementation of the CSR within the big company is usually part of the firm policy, mainly at international companies. Management of the company considers this desirable and its own realization is real because the company can set aside the financial 
as well as human sources for CSR implementation. The situation is different with the small firms. CSR implementation within the small company is difficult, respectively is not purposefully implemented. Small firms cannot set aside financial or human sources. The management is not usually aware of the CSR principles and CSR possibilities. Despite the fact, that the activities of the CSR are in the firms naturally carried out without the firms' knowledge. The requirement is for small companies to apply the CSR principles systematically. The text carried out the case study in the selected small firms, which were not aware of the CSR concept, but they were interested in this theme. For the representatives, the interesting was already the progress of the project, when they understood and named the firms' priorities (in accordance with the CSR) and gradually they started to determine the specific criteria in the context of their specific firm environment. The outputs gave them the feedback that they actually use some of the CSR principles already. While discussion, it was stated, that the CSR concept is required for the firm itself, that it is useful and feasible and that the deeper systematic implementation is suitable.

Evaluation of the case study was done just before the worldwide pandemic. After the quarantine finished, the situation was discussed informally with both firms representatives. In the discussion was mentioned, that the firm must work with limits at once, the production was changed, and alternative procedures were searched and the inspiration was found to the less demanding procedures. The health situation had a positive impact on the environment. Not only that the production was reduced, but also home-office was introduced. Some of the firms had not used the home-office before or thought that it was not a suitable tool in their environment, but they changed their opinion and started it. In the quarantine the hygienic conditions were improved, and the firms tried to keep the cleanliness more at the workplaces. It is assumed to be kept in the future, which can help to a better image of the firm. Another aspect, which can help the firm image and relates to the longer quarantine is the firm's philanthropy. During the quarantine, some of the firms tried to support some organizations or people 'in the front line', which can be understood as the activity of the firm's philanthropy. This discussion had a general character, but it was clear that it can be used as inspiration for other development in the near future.

Acknowledgment - this article was supported by the grant No. SGS_2020_18 of the Student Grant Competition.

\section{References}

1. European Commission (2020, May 5). A renewed EU Strategy 2011-2014 for Corporate Social Responsibility, Document 52011DC0681. https://eurlex.europa.eu/legal-content/EN/TXT/?uri=CELEX:52011DC0681

2. Ministry of Industry and Trade of the Czech Republic (2020, June 12). Národni informační portál o CSR. https://www.narodniportal.cz/csr-v-cr/

3. Bell, S., Morse, S., Shah, R.A. (2012). Understanding stakeholder participation in research as part of sustainable development. Journal of Environmental Management, $101,13-22$.

4. Prashantham, S., Birkinshaw, J. (2020). MNE-SME cooperation: An integrative framework. Journal of International Business Studies, 51(7), 1161-1175.

5. Mikulcic, H., Duic, N., et al. (2019). Troubleshooting the problems arising from sustainable development. Journal of Environmental Management, 232, 52-57.

6. Ministry of Industry and Trade of the Czech Republic (2020, June 14). The National Action Plan for Corporate Social Responsibility in the Czech Republic 2019-2023. https:www.komora.cz/legislation/79-18-narodni-akcni-plan-spolecenske-odpovednosti 
7. Simonova, S., Foltanova, N. (2018). Applying the Global Principles of the Sustainable Development for Better Quality of Life: Proceedings of the Globalization and its Socio-Economic Consequences (pp. 2797-2804). Rajecke Teplice, Slovakia.

8. WHO. (2020, June 15). European Healthy Cities Network. http://www.euro.who.int/en/health-topics/environment-and-health/urban-health/

9. UN Development Programme. (2020, June 15). The 2030 Agenda for Sustainable Development. https://www.un.org/sustainabledevelopment

10. WHO. Health 2020. http://www.euro.who.int/en/health-topics/health-policy/health2020-the-european-policy-for-health-and-well-being

11. UVCR - Government of the Czech Republic ÚV ČR. (2017). Strategický rámec ČR 2030. Praha: Polygrafie Úřadu vlády ČR.

12. European Commission. Corporate Social Responsibility. https://ec.europa.eu/growth /industry/sustainability/corporate-social-responsibility_en

13. Kust, G., Andreeva, O., Cowie, A. (2017). Land Degradation Neutrality: Concept development, practical applications and assessment. Journal of Environmental Management, 195(1), 16-24.

14. CSR. The European Business Network for Corporate Sustainability and Responsibility (2020, June 20). https://www.csreurope.org/

15. Barnett, M.L., Henriques, I., Husted, B.W. (2020). Beyond Good Intentions: Designing CSR Initiatives for Greater Social Impact. Journal of Management, 46(6), 937-964.

16. Kasparova, K., Kunz, V. (2013) Moderni přistupy ke společenské odpovědnosti firem a CSR reportování. Praha: Grada Publishing. 160 p. ISBN 978-80-247-4480-3.

17. Fenton, P., Gustafsson, S. (2017). Moving from high-level words to local action. Current Opinion in Environmental Sustainability, 26-27, 129-133.

18. Brandt, U.S., Svendsen, G.T. (2013). Is local participation always optimal for sustainable action? The costs of consensus-building in Local Agenda 21. Journal of Environmental Management, 129, 266-273.

19. Shen, J., Benson, J. (2016). When CSR Is a Social Norm: How Socially Responsible Human Resource Management Affects Employee Work Behavior. Journal of Management, 42(6), 1723-1746.

20. Selmier, W., Travis, I., Newenham-Kahindi, A., Oh, C.H. (2015). Understanding the words of relationships: Language as an essential tool to manage CSR in communities of place. Journal of International Business Studies, 46(2), 153-179.

21. Suebvises, P. (2018). Social capital, citizen participation in public administration, and public sector performance in Thailand. World Development, 109, 236-248.

22. Vochozkova, J., Trhlinova, Z. (2016). Criteria and Indicators for Assessing the Sustainability of Spatial Development on the Example of the Local Agenda 21: Proceedings of the Globalization and Its Socio-Economic Consequences. Rajecke Teplice, Slovakia, p. 2392-2400.

23. Rathert, N. (2016). Strategies of legitimation: MNEs and the adoption of CSR in response to host-country institutions. Journal of International Business Studies, 47(7), 858-87.

24. TPCA. Responsibility (2020, July 2). http://en.tpca.cz/about-us/responsibility/

25. Vrtackova, N. (2020). Společenská odpovědnost v menši firmě. Univerzita Pardubice. 